\title{
UJI EFEKTIVITAS EKSTRAK AIR IKAN HARUAN (Channa striata) ASAL KALIMANTAN SELATAN TERHADAP BLEEDING TIME DAN CLOTTING TIME SECARA IN VIVO
}

\author{
THE EFFECTIVENESS OF SNAKEHEAD FISH (Channa striata) \\ WATER EXTRACT FROM SOUTH KALIMANTAN OF \\ BLEEDING TIME AND CLOTTING TIME IN VIVO
}

\author{
Norhalifah, Dina Rahmawanty, Nurlely \\ Program Studi Farmasi, Universitas Lambung Mangkurat \\ Email: dinarahmawanty@gmail.com
}

\begin{abstract}
ABSTRAK
Ikan haruan memiliki kandungan albumin yang tinggi, mengandung asam amino yang dapat meningkatkan daya tahan tubuh dan membantu proses penyembuhan luka. Penelitian ini bertujuan untuk menguji efektivitas ekstrak air ikan haruan (Channa striata) terhadap bleeding time dan clotting time tikus putih jantan yang mengalami luka dan menentukan dosis ekstrak air ikan haruan yang paling efektif menurunkan bleeding time dan clotting time. Jenis penelitian yang digunakan penelitian eksperimental murni (true experimental design). Tiga puluh tikus jantan dibagi menjadi 5 kelompok. Kelompok I (kontrol negatif), kelompok II (kontrol positif), kelompok III, IV dan V kelompok ekstrak air ikan haruan konsentrasi 10\%, 20\% dan $40 \%$. Ekstrak air ikan haruan berupa ekstrak kental yang diencerkan dengan akuades, sehingga dosis ekstrak air ikan haruan dibuat dalam konsentrasi persen (\%). Hewan uji diberi injeksi heparin secara sub kutan selama 5 hari, kemudian diberi sediaan uji selama 5 hari dicatat bleeding time dan clotting time tiap 2 hari sekali selama pemberian sediaan uji. Analisis data menggunakan Two Way Anova. Hasil penelitian menunjukkan persentase daya penurunan bleeding time dari semua kelompok meliputi kontrol negatif, kontrol positif, ekstrak air ikan haruan 10\%, 20\% dan 40\% berturut-turut yaitu 48,36\%; 67,36\%; 72,37\%; 75,21\%; 82,10\% dan persen daya penurunan clotting time berturut-turut yaitu 52,70\%; 70,29\%; 76,61\%; 76,89\%; dan $78,93 \%$. Kesimpulan penelitian ini ekstrak air ikan haruan mampu menurunkan bleeding time dan clotting time pada tikus putih jantan yang mengalami luka dengan dosis efektif $40 \%$.
\end{abstract}

Kata kunci : ekstrak (Channa striata), bleeding time, clotting time, secara in vivo 


\section{ABSTRACT}

Snakehead fish has a high content of albumin, containing amino acids that may increase body endurance and help the healing process of wounds. This research aimed to evaluate the effect of snakehead fish (Channa striata) water extract on bleeding time and clotting time of injured male rats and deciding the most effective dose to decreasing bleeding time and clotting time. Kind of research that used is true experimental design. Thirty white male rats are divided into five groups, 1st group (negative control), 2nd group (positive control), 3rd, 4th and 5th group is 10\%, 20\% and $40 \%$ of snakehead fish water extract.Snakehead fish water extract are madefrom condensed extract that be diluted with aquadest then make info their percent concentrate.Test animals were injected with heparin sub-cutaneously within 5 days, then given the test sample within 5 days bleeding time and clotting time and recorded every 2 days during the administration of the test sample.Analysis of data using Twoway anova. The result of this research were snakehead fish water extract can reduce of bleeding time from each group, negative group, positive control, 10\%, 20\% and $40 \%$ are $48.38 \% ; 67.36 \% ; 72.37 \% ; 75.21 \% ; 82.10 \%$ and decrease of clotting are 52.70\%; 70.29\%; 76.61\%; 76.89\%; and 78.93\%. The Conclusion of this research were $40 \%$ snakehead fish water extract are most effecting to reduce bleeding time and clotting time.

Keywords: (Channa striata)extract, bleeding time, clotting time, in vivo

\section{PENDAHULUAN}

Ikan haruan banyak ditemukan di wilayah perairan di Indonesia seperti di daerah Sumatera, Jawa dan Kalimantan Selatan. Sebagian besar masyarakat Kalimantan Selatan mempercayai bahwa ikan haruan dapat mempercepat penyembuhan luka. Hal ini didukung oleh penelitian Mat Jais (2007) yang menyatakan ikan haruan dapat digunakan sebagai terapi dalam penyembuhan luka, khususnya untuk luka sesudah operasi. Ikan haruan memiliki kandungan albumin yang tinggi, mengandung asam amino yang dapat meningkatkan daya tahan tubuh dan membantu proses penyembuhkan luka (Musdalifah, 2013). Ikan haruan dari berbagai daerah memiliki perbedaan kandungan asam amino tergantung dari jenis pakan yang diberikan dan adanya perbedaan habitat menyebabkan adanya perbedaan bentuk tubuh ikan haruan (Hermiastuti, 2013). Luka dapat dikategorikan menjadi dua yaitu luka yang berdarah dan luka tidak berdarah. Bleeding (pendarahan) merupakan tahapan awal ketika terjadi luka, jika pendarahan terjadi dalam jangka waktu yang 
lama maka tahapan selanjutnya juga akan berlangsung lama (Langenecker et al., 2013). Bleeding time (waktu pendarahan) adalah waktu pertama kali saat darah menetes sampai terhenti sedangkan clotting time (waktu pembekuan) merupakan waktu yang diperlukan darah untuk membeku (Putri, 2013). Luka akan cepat sembuh jika proses penyembuhan luka juga berlangsung cepat.

Penyembuhan luka merupakan proses perbaikan atau pemulihan dari kerusakan suatu organ atau jaringan, biasanya terjadi pada jaringan kulit (Gurtner, 2007). Proses penyembuhan luka terjadi dengan cepat apabila bleeding time dan clotting time berlangsung dengan cepat. Pembekuan darah berguna untuk mencegah terlalu banyak pendarahan dan mencegah penyebaran infeksi ke jaringan yang sehat (Flanagan, 2000). Banyak senyawa obat yang dapat mempercepat penyembuhan luka, salah satu diantaranya adalah penggunaan ekstrak air ikan haruan (Daud et al., 2010) sebagai terapi dalam penyembuhan luka.

\section{METODOLOGI PENELITIAN}

Alat-alat yang digunakan antara lain alat-alat gelas (Iwaki ${ }^{\circledR}$, Pyrex $^{\circledR}$ ), panci pressure cooker $\left(\right.$ Tianchi $^{\circledR}$ ), batang pengaduk, mortir, hot plate (Maspion ${ }^{\circledR}$ ), neraca analitik (IND GF-3000 ${ }^{\circledR}$ ), pipet tetes, rotary evaporator $\left(\mathrm{Merck}^{\circledR}\right)$, spuit injeksi $\left(\right.$ Onemed $\left.^{\circledR}\right)$, sendok tanduk, stamper, stopwatch, sonde oral, timbangan tikus $\left(\right.$ Precise $^{\circledR}$ ) dan waterbath.

Bahan-bahan yang digunakan antara lain akuades, etanol 70\%, kasa steril, daging ikan haruan, asam traneksamat (Kalbe Farma ${ }^{\circledR}$ ), larutan normal salin (Widatra Bhakti $\left.^{\circledR}\right)$ dan kertas saring.

Jalannya Penelitian

A. Determinasi Ikan Haruan (Channa striata)

Ikan haruan (Channa striata) dideterminasi di laboratorium Biologi Program Studi Biologi FMIPA UNLAM Banjarbaru. 
B. Preparasi Daging Ikan haruan (Channa striata)

Ikan haruan yang akan digunakan pada penelitian ini diperoleh dari Dinas Pertanian dan Perikanan Kota Banjarmasin, Kalimantan Selatan. Masing-masing ikan haruan yang digunakan memiliki berat antara 250-400 gram, dengan panjang badan antara 16-38 cm (diukur dari kepala sampai ekor) (Mat Jais et al., 1997). Ikan haruan dibersihkan dari sisiknya, lalu dicuci bersih. Bagian daging diambil dan dipisahkan dari bagian lainnya. Bagian daging yang telah dipisahkan dimasukan ke dalam wadah.

\section{Proses Ekstraksi Air Ikan Haruan (EAIH)}

Proses ekstraksi air ikan haruan dilakukan dengan pressure cooker dengan suhu $100^{\circ} \mathrm{C}$ selama 60 menit. Fillet segar tanpa tulang ditimbang terlebih dahulu, lalu dimasukkan ke dalam pressure cooker serta diisi akuades. Rasio akuades yang ditambahkan adalah 1:1 (daging ikan haruan:akuades) dan ekstraksi dilakukan melalui proses pressure cooker. Pada akhir proses ekstraksi, fillet dibuang sedangkan ekstrak air yang diperoleh dikumpulkan dan disaring dengan kertas saring. Hasil ekstraksi dipekatkan dengan dengan rotary evaporator dan diuapkan di atas waterbath sampai terbentuk ekstrak kental (Daud et al., 2010).

D. Persiapan Hewan Uji

Hewan coba yang digunakan pada penelitian ini adalah tikus putih jantan galur Wistar. Jumlah yang digunakan dalam penelitian ini sebanyak 30 ekor yang dibagi menjadi 5 kelompok perlakuan dengan masing-masing kelompok berjumlah 6 ekor tikus. Setiap kelompok ditempatkan dalam kandang terpisah. Tikus terlebih dahulu diadaptasikan di dalam kandangnya.

E. Uji Pendahuluan (Orientasi Dosis)

Dilakukan uji pendahuluan dengan orientasi dosis terhadap ekstrak air ikan haruan dan asam traneksamat. Dosis ekstrak air ikan haruan dibagi menjadi dua kelompok, kelompok I diberikan ekstrak air ikan haruan $2 \mathrm{~mL} / \mathrm{kg}$ BB dan kelompok II diberikan ekstrak air ikan haruan $8 \mathrm{~mL} / \mathrm{kg}$ BB masing-masing secara per oral tiap kelompok terdiri 2 ekor tikus (Nicodemus et al., 2014). 
F. Pengamatan Bleeding Time

Pengamatan bleeding time dilakukan dengan menggunakan modifikasi pemotongan ekor tikus. Tikus diletakkan dalam restrainer ekor tikus dikeluarkan melalui lubang yang sudah tersedia (Rajasekaran et al., 2010). Ekor tikus dipijat terlebih dahulu sebelum dilakukan pemotongan (Asika et al., 2011) dan kemudian dipotong $2 \mathrm{~mm}$ menggunakan gunting bedah (Rajasekaran et al., 2010). Ekor tikus segera dimasukan ke dalam larutan normal salin. Stopwatch segera dinyalakan setelah ekor tikus dimasukan ke dalam larutan normal salin. Waktu pendarahan dimulai saat ekor dimasukan ke dalam larutan normal salin dan berhenti saat tidak terjadi lagi pendarahan (Rajasekaran et al., 2010). Pemotongan ekor tikus dilakukan sebanyak 4 kali, yaitu T0: sebelum dilakukan pemberian ekstrak air ikan haruan, T1: pada hari ke 2 setelah dilakukan pemberian ekstrak air ikan haruan, T2: pada hari ke 4 setelah dilakukan pemberian ekstrak air ikan haruan dan T3: pada hari ke 6 setelah dilakukan pemberian ekstrak air ikan haruan. Pemberian ekstrak air ikan haruan diberikan secara oral menggunakan sonde oral (Apriyani et al., 2011).

\section{G. Pengamatan Clotting Time}

Pengamatan untuk clotting time dilakukan dengan memotong ekor tikus. Tikus diletakkan dalam restrainer ekor tikus dikeluarkan melalui lubang yang sudah tersedia (Rajasekaran et al., 2010). Ekor tikus dipijat terlebih dahulu sebelum dilakukan pemotongan (Asika et al., 2011) dan kemudian dipotong $2 \mathrm{~mm}$ menggunakan gunting bedah (Rajasekaran et al., 2010). Disiapkan pipa kapiler non heparin di bawah ekor tikus untuk menampung darah yang akan menetes dan segera nyalakan stopwatch saat darah mulai keluar. Pipa kapiler dipatahkan pada 30 detik kemudian setiap 15 detik berikutnya dilakukan pematahan pipa kapiler. Stopwatch dihentikan saat pipa kapiler yang dipatahkan sudah terbentuk benang fibrin dan dicatat waktunya. Pipa kapiler diletakkan untuk menampung darah sebanyak 4 kali, yaitu T0: sebelum dilakukan pemberian ekstrak air ikan haruan, T1: pada hari ke 2 setelah dilakukan pemberian ekstrak air ikan haruan, T2: pada hari ke 4 setelah dilakukan pemberian ekstrak air ikan haruan dan T3: pada hari ke 6 setelah dilakukan 
pemberian ekstrak air ikan haruan. Pemberian ekstrak air ikan haruan diberikan secara oral menggunakan sonde oral (Apriyani et al., 2011).

H. Analisis Data

Data bleeding time dan clotting time dianalisis statistik dengan Two Way ANOVA. Perbedaan antar kelompok di uji dengan levene's test dan Post Hoc Tuckey $H S D$.

\section{HASIL DAN PEMBAHASAN}

\section{A. Penyiapan Bahan}

Bahan yang digunakan dalam penelitian ini adalah ikan haruan. Ikan haruan diambil dari Dinas Pertanian dan Perikanan kota Banjarmasin, Kalimantan Selatan dan dideterminasi di Laboratorium Dasar FMIPA Universitas Lambung Mangkurat. Ikan haruan dibersihkan dari sisiknya, lalu dicuci bersih dan diambil dagingnya. Ikan Haruan yang digunakan dalam penelitian ini memiliki berat 250-400 gram dan panjang ikan antara 25-38 cm (diukur dari kepala sampai ekor). Hal ini bertujuan untuk memperoleh kandungan zat berkhasiat khususnya protein dalam jumlah maksimal sehingga apabila berat dan panjang ikan terlalu besar maka zat berkhasiat dalam ikan haruan jumlahnya tidak maksimal (Gam et al., 2006).

B. Proses Ekstraksi

Proses ekstraksi daging ikan haruan pada penelitian ini dilakukan dengan menggunakan pressure cooker menggunakan pelarut akuades. Pemilihan pelarut dalam metode ekstraksi didasarkan pada prinsip ekstraksi "like dissolve like" yang berarti senyawa polar akan berikatan dengan pelarut polar dan begitu sebaliknya (Gunawan, 2004). Akuades bersifat polar sehingga dapat melarutkan asam amino yang terkandung dalam ikan haruan yang berperan dalam penyembuhan luka (Depkes RI, 1979., Zakaria et al., 2007).

Hasil ekstraksi dipekatkan terlebih dahulu menggunakan rotary evaporator selama 4 jam dengan suhu $50^{\circ} \mathrm{C}$, kemudian diuapkan di atas waterbath sampai terbentuk ekstrak kental. Ekstrak kental daging ikan haruan yang diperoleh berwarna 
putih kekuningan dengan bobot sebesar 30,02 gram dan persentase rendemen yang diperoleh pada penelitian ini sebesar 3,99\%.

C. Uji Pendahuluan (Orientasi Dosis)

Hasil orientasi dosis untuk ekstrak air ikan haruan menunjukkan bahwa kelompok I dengan dosis $2 \mathrm{~mL} / \mathrm{kg}$ BB dapat menurunkan bleeding time dan clotting time dengan perubahan waktu secara bertahap dan tidak menyebabkan kematian pada tikus, sedangkan untuk kelompok II dengan dosis $8 \mathrm{~mL} / \mathrm{kg}$ BB dapat menurunkan bleeding time dan clotting time dan menyebabkan kematian pada hewan uji. Ekstrak air ikan haruan berupa ekstrak kental sehingga perlu dilakukan pengenceran dengan akuades, oleh karena itu dosis ekstrak air ikan haruan dibuat dalam konsentrasi persen (\%). Berdasarkan uraian di atas maka rentang dosis ekstrak air ikan haruan yang digunakan yaitu 10\%, 20\% dan 40\% bertujuan untuk mengevaluasi diantara ketiga rentang dosis yang dapat menurunkan bleeding time dan clotting time yang paling efektif. Konsentrasi dosis ekstrak air ikan haruan 10\% berarti 1 gram ekstrak kental dilarutkan dengan akuades sampai $10 \mathrm{~mL}$.

Dosis asam traneksamat dibagi menjadi dua kelompok, kelompok I diberikan asam traneksamat dengan dosis $0,18 \mathrm{mg} / \mathrm{kg}$ BB (Benon dan Fredin, 1996) sedangkan kelompok II diberikan asam traneksamat dengan dosis 0,27 mg/kg BB (Mannucci, 1998) masing-masing secara per oral tiap kelompok terdiri 2 ekor tikus. Hasil orientasi dosis untuk asam traneksamat menunjukkan bahwa kelompok I dengan dosis $0,18 \mathrm{mg} / \mathrm{kg} \mathrm{BB}$ dapat menurunkan bleeding time dan clotting time dengan perubahan waktu secara bertahap dan tidak menyebabkan kematian pada tikus sedangkan untuk kelompok II dengan dosis $0,27 \mathrm{mg} / \mathrm{kg}$ BB dapat menurunkan bleeding time dan clotting time dan menyebabkan kematian 1 ekor tikus. Berdasarkan uraian di atas maka dosis asam traneksamat yang digunakan yaitu $0,18 \mathrm{mg} / \mathrm{kg} \mathrm{BB}$ karena pada dosis ini tidak menyebabkan kematian terhadap hewan uji dan dapat menurunkan bleeding time dan clotting time. 
D. Pengamatan Bleeding Time

Pemberian sediaan uji dilakukan selama 5 hari yaitu dari hari ke 9 sampai hari ke 13. Setiap 2 hari sekali setelah pemberian sediaan uji dilakukan pengamatan bleeding time. Hasil pengamatan bleeding time untuk kelompok kontrol positif dengan pemberian asam traneksamat mampu menurunkan waktu pendarahan terlihat dari hasil yang didapat semakin lama pemberian asam traneksamat maka waktu pendarahan juga semakin singkat. Persentase penurunan bleeding time dihitung dari data yang diperoleh, sehingga diperoleh berapa besar daya penurunan (\%) bleeding time setelah perlakuan. Daya penurunan (\%) bleeding time (waktu pendarahan) setelah perlakuan terhadap bleeding time (waktu pendarahan) setelah injeksi heparin (Th) untuk kelompok ekstrak air ikan haruan (EAIH) 40\% terjadi penurunan waktu pendarahan lebih besar dibandingkan dengan kelompok kontrol negatif dan kelompok dosis (EAIH) $10 \%$ ataupun 20\%. Grafik hubungan nilai rata-rata pengamatan penurunan bleeding time terhadap waktu pengamatan dapat dilihat pada Gambar 1.

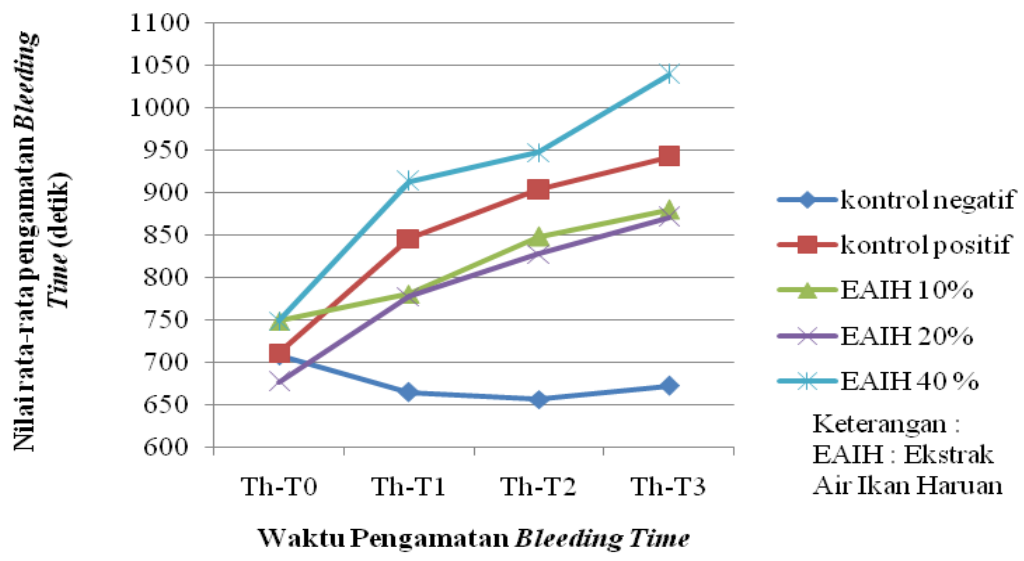

Gambar 1. Grafik hubungan nilai rata-rata pengamatan bleeding time terhadap waktu pengamatan bleeding time

Data Gambar 1 memperlihatkan terjadi peningkatan nilai rata-rata pengamatan bleeding time untuk kelompok kontrol positif, EAIH 10\%, 20\% dan 40\% setelah semakin lamanya waktu pengamatan, sedangkan untuk kelompok kontrol negatif mengalami penurunan nilai rata-rata pengamatan bleeding time. Berdasarkan data 
grafik untuk dosis ekstrak air ikan haruan $40 \%$ terus mengalami peningkatan nilai rata-rata pengamatan bleeding time. Ekstrak air ikan haruan dapat menurunkan waktu pendarahan (bleeding time) karena ekstrak haruan mengandung protein, asam lemak, mineral penting seperti Fe dan Zn (Daud et al., 2010., Mustafa et al., 2012).

Protein tersusun atas asam amino berfungsi untuk regenerasi dan perbaikan jaringan, sehingga dapat membantu mempercepat penyembuhan luka. Bleeding time berkaitan erat dengan proses penyembuhan luka. Ketika terjadi pendarahan platelet akan melekat pada makromolekul di daerah subendotelium pembuluh darah yang luka kemudian terbentuk agregasi platelet membentuk sumbat hemostatik utama. Platelet merangsang aktivasi faktor-faktor koagulasi di dalam plasma menyebabkan pembentukan bekuan fibrin yang mendorong terbentuknya agregat platelet kemudian benang-benang fibrin akan terbentuk. Pembentukan benang fibrin dibantu oleh kolagen dengan komponen penyusun berupa asam amino yang terkandung dalam ikan haruan (Goodman dan Gilman, 2008).

\section{E. Pengamatan Clotting Time}

Hasil pengamatan clotting time untuk kelompok kontrol positif dengan pemberian asam traneksamat mampu menurunkan clotting time terlihat dari hasil yang didapat semakin lama pemberian asam traneksamat maka clotting time juga semakin singkat. Kelompok kontrol negatif dengan pemberian akuades menunjukkan hasil yang berbeda dengan kontrol positif terlihat hasil pengamatan clotting time sebelum dan sesudah perlakuan tidak terdapat perubahan. Waktu pengamatan clotting time pada Th-T0, Th-T1, Th-T2 dan Th-T3 terdapat perbedaan satu sama lain.

Berdasarkan data yang diperoleh dihitung selisih waktu pendarahan tiap kelompok pengamatan terhadap waktu setelah diinjeksi heparin (Th) kemudian dianalisis dengan Two Way Anova. Daya penurunan (\%) clotting time (waktu pembekuan) setelah perlakuan terhadap clotting time (waktu pembekuan) setelah injeksi heparin (Th) untuk kelompok ekstrak air ikan haruan (EAIH) 40\% terjadi penurunan waktu pendarahan lebih besar dibandingkan dengan kelompok kontrol negatif dan kelompok dosis (EAIH) $10 \%$ ataupun 20\%. Grafik hubungan nilai rata- 
rata pengamatan penurunan clotting time terhadap waktu pengamatan dapat dilihat pada Gambar 2.

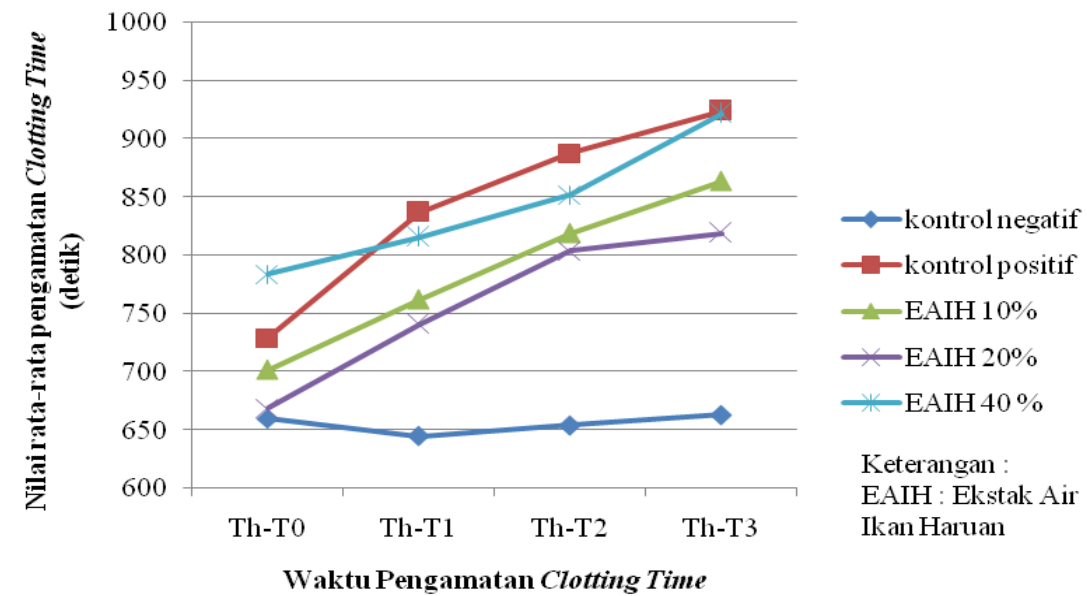

Gambar 2. Grafik hubungan nilai rata-rata pengamatan clotting time terhadap waktu pengamatan clotting time

Data Gambar 2 memperlihatkan terjadi peningkatan nilai rata-rata pengamatan clotting time untuk kelompok kontrol positif, EAIH 10\%, 20\% dan 40\% seiring dengan semakin lamanya waktu pengamatan, sedangkan untuk kelompok kontrol negatif mengalami penurunan nilai rata-rata pengamatan clotting time.

Asam amino yang terdapat dalam ikan haruan dapat mempercepat penyembuhan luka. Clotting time berkaitan erat dengan proses penyembuhan luka. Proses koagulasi yaitu perubahan fibrinogen menjadi fibrin (Katzung, 2001). Trombin mengubah fibrinogen menjadi monomer-monomer fibrin dengan memutuskan fibrinopeptida A dan fibrinopeptida B. Pemindahan fibrinopeptida menyebabkan monomer fibrin membentuk gel yang terikat satu sama lain. Selanjutnya faktor XIIIa mengkatalis reaksi transglutaminasi antar rantai yang menyambung monomer fibrin yang berikatan untuk meningkatkan kekuatan bekuan. Pembentukan benang fibrin dibantu oleh kolagen dimana asam amino yang terkandung dalam ikan haruan merupakan komponen penyusun kolagen (Goodman dan Gilman, 2008). 


\section{KESIMPULAN}

Ekstrak air ikan haruan berpengaruh terhadap bleeding time dan clotting time tikus putih jantan yang mengalami luka. Dosis ekstrak air ikan haruan yang paling efektif menurunkan bleeding time dan clotting time adalah dosis ekstrak air ikan haruan $40 \%$ dengan kemampuan menurunkan bleeding time sebesar 82,10\% dan untuk clotting time sebesar 78,93\%.

\section{DAFTAR PUSTAKA}

Apriyani, S., Sunarni, T., dan Ningsih, D., 2011, Efek Ekstrak Etanol Herba Bandotan (Ageratum conyzoides, L.) terhadap Waktu Perdarahan dan Pembekuan Darah pada Tikus Putih Jantan (Rattus norvegicus), Jurnal Farmasi Indonesia, 8 (1): 77-84.

Asika, E.C., Idonije, B.O., Okha, O., and Oiribhoge, I., 2011, Preliminary investigation of antithrombotic activities of methanolic seed extracts of Garcinia Combogia in rats, Annals of Biological Research, 2 (3): 333-346.

Benon, G. and Fredin, H., 1996, Fibrinolytic Inhibition with Tranexamic Acid Reduces Blood Loss and Blood Transfusion after Knee Arthroplasty, J Bone Joint Surg [Br], 78 (B): 434-40.

Daud, C.K.D., Mat Jais, A.M., Ahmad, Z., Akim, A.M., and Adam A., 2010, Amino and fatty acid composition in haruan traditional extract (THE), Boletín Latinoamericano y del Caribe de Plantas Medicinales y Aromáticas. 9 (5): $414-429$.

Depkes RI, 1979, Farmakope Indonesia, Edisi III, Departemen Kesehatan Republik Indonesia, Jakarta.

Flanagan, M., 2000, The physiology of wound healing. Principal Lecturer, University of Hertfordshire, UK, Journal of wound care june, 9 (6): 299-300.

Gam, L.H., Leow, C.Y., and Baie, S., 2006, Proteomic Analysis od Fnakehead Fish (Channa striata) Muscle Tissue, Malaysian Journal of Biochemistry and Molecular Biology, 14: 25-32.

Gunawan, D., 2004, Ilmu Obat Alam (Farmakognosi), Jilid I, Penerbit Swadaya, Yogyakarta. 
Gurtner, G.C., 2007, Chapter 2 Wound Healing: Normal and Abnormal. Grabb and Smith's Plastic Surgery, Sixth Edition.

Goodman dan Gilman, 2008, Dasar Farmakologi Terapi, Volume 2, Penerbit Buku Kedokteran EGC.

Hermiastuti, M., 2013, Analisis Kadar Protein dan Identifikasi Asam Amino pada Ikan Patin (Pangasius djambal), Skripsi, Fakultas Matematika dan Ilmu Pengetahuan Alam, Universitas Jember.

Katzung B.G., 2001, Farmakologi Dasar Klinik, Penerbit Salemba Medika.

Langenecker, S.A.K., Afshari, A., Albaladejo, P., Santullano, C.A.A., Robertis, E.D., Filipescu, D.C., Fries, D., Gorlinger, K., Haas, T., Imberger, G., Jacob, M., Lance, M., Llau, J., Mallett, S., Meier, J., Rahe-Meyer, N., Samama, C.N., Smith, A., Solomon, C., Linden, P.V., Wikkelso, A.J., Wouters, P., and Wyffels, P., 2013, Management of severe perioperative bleeding. Guidelines from the European Society of Anaesthesiology, Eur J Anaesthesiol. 30: 270382.

Mannucci, P.M.M.D., 1998, Hemostatic Drugs, The New England Journal of Medicine, 339 (4): 245-253.

Mat Jais, A.M., Dambisya Y.M., and Lee T.L., 1997, Antinociceptive activity of Channa striatus (haruan) extracts in mice, Journal of Ethnopharmacology, 57: 125-130.

Mat Jais, A.M., 2007, Pharmacognosy and Pharmacology of Haruan (Channa striatus) a Medical Fish with Wound Healing Properties. Bol. Latinoam. Caribe Plant, Med. Aromaticas, 6: 52-60.

Musdalifah, U., 2013, Studi Pembuatan Biskuit dengan Substitusi Tepung Ikan Gabus (Ophiocephalus striatus), Skripsi, Teknologi Pertanian Fakultas Pertanian Universitas Hasanuddin Makassar.

Mustafa, A., Widodo, M.A., and Kristanto, Y., 2012, Albumin and Zinc Content of Snakehead Fish (Channa striata) Extract and Its Role in Health, International Journal of Science anf Technology, 1 (2): 1-8.

Nicodemus, Andrie, M., and Luliana, S., 2014, Uji Efek Penyembuhan Luka Sayat Ekstrak Ikan Toman (Channa micropeltes) secara Oral pada Tikus Putih Jantan Wistar, Jurnal Farmasi Indonesia, 5 (1): 77-84. 
Putri, Y., 2013, Pemberian ekstrak batang pisang ambon terhadap stabilitas sediaan gel ekstrak batang pisang ambon (Musa paradisiaca), Skripsi, Universitas Airlangga.

Rajasekaran, A., Kalaivani, M., and Ariharasivakumar, A., 2010, Haemostatic effect of fresh juice and methanolic extract of Eupatorium leaves in rat model, International Journal of Biological \& medical Research, 1 (2): 85-87.

Zakaria, Z.A., Mat Jais, A.M., Goh, Y.M., Sulaiman, M.R., and Somchit, M.N., 2007, Amino acid and fatty acid composition of an aqueous extract of Channa striatus (haruan) that exhibits antinociceptive activity, Clinical and experimental pharmacologi and physiology, 34: 198-204. 